\title{
Pro dan Kontra Penerapan ASEAN Open Sky bagi Negara Anggota ASEAN
}

\section{Dedi Prasetyo*}

dedi_pras555@webmail.umm.ac.id

Program Studi Hubungan Internasional, Fakultas Ilmu Sosial dan Ilmu Politik, Universitas

Muhammadiyah Malang

\begin{abstract}
Abstrak
Liberalisasi penerbangan di kawasan regional Asia Tenggara sudah cukup lama diinisiasi dan telah diberlakukan sejak 2015 dalam bentuk kebijakan ASEAN Open Sky. Impelementasi kebijakan ASEAN Open Sky yang bertujuan untuk memberikan akses penuh maskapai penerbangan negara-negara Asia Tenggara memicu perdebatan. Terdapat pihak yang setuju maupun yang menentang. Dalam penelitian ini, penulis bertujuan membedah untung-rugi penerapan kebijakan ASEAN Open Sky bagi negara-negara anggota ASEAN. Fokus analisis menekankan pada dampak ASEAN Open Sky bagi negara-negara Asia Tenggara, dimana kebijakan ini merupakan salah satu upaya untuk menyukseskan Pilar Masyarakat Ekonomi ASEAN. Pendekatan liberal institusional digunakan untuk memahami fokus permasalahan studi. Metode pengumpulan data menggunakan studi literatur. Teknik pengolahan data menggunakan konsep analisa SWOT (Strength, Weakness, Opportunity, and Threat) Tunggal menurut Freddy Rangkuti. Hasil penelitian menggambarkan dampak ASEAN Open Sky sangat menguntungkan Singapura dan Malaysia, sedangkan Indonesia dan Filipina negara yang cenderung dirugikan.
\end{abstract}

Kata Kunci: ASEAN, kebijakan, Open Sky, penerbangan, SWOT.

\begin{abstract}
Flight liberalization in South East Asia Region has long been initated and implemented since 2015 under the name of ASEAN Open Sky Policy. The implementation of this policy which is aimed to give a full access to the flight companies in ASEAN countries triggers a debate. There are pros and cons about it. Through this research, the writer intends to analyse cost and benefit of the implementation of that policy to the ASEAN countries. The focus of the analysis is on the impact of ASEAN Open Sky Policy to the countries in the region where the policy contributes to the ASEAN Economic Community. This research uses liberal institutional approach. The method is literature studi. Data processing technique uses single SWOT analytic concept. The result shows that the effect of ASEAN Open Sky is more beneficial to Singapore and Malaysia rather than to Indonesia and the Philippines.
\end{abstract}

Keywords: ASEAN, flight, Open Sky, policy, SWOT.

\section{Pendahuluan}

Kerjasama regional yang terdapat di Asia Tenggara berkembang seiring waktu. Ide awal pembentukan ASEAN disebabkan respon pengaruh politik dan keamanan, seperti Politik Konfrontasi Indonesia-Malaysia tahun 1962 dan konflik Filipina-Malaysia tahun 1961. Sejak awal berdirinya ASEAN, kerjasama politik dan keamanan regional merupakan target utama regional. Kebutuhan ekonomi masing-masing negara mendorong ASEAN untuk mengadakan kerjasama regional di bidang ekonomi. ASEAN pada akhirnya menjadi organisasi regional yang beraktifitas di sektor politik, keamanan, kebudayaan, dan ekonomi (Cipto, 2010).

Beberapa faktor yang mendorong ASEAN mengadakan kerjasama ekonomi baik dari internal maupun eksternal. Faktor internal seperti motivasi baru untuk mempertahankan relevansi ASEAN sebagai organisasi regional, serta keinginan bersama untuk menarik para investor asing. Faktor elesternal seperti pengaruh NAFTA dan EU, dua organisasi regional yang mengembangkan

\footnotetext{
* Korespondensi: Dedi Prasetyo, GKB I lt 6, Kampus III UMM, Jl. Raya Tlogomas 246, Malang, Jawa Timur 65144, Indonesia.
} 
kerjasama ekonomi yang kemudia diadaptasi ASEAN untuk mengadakan ASEAN Free Trade Area (AFTA) (Cipto, 2010).

ASEAN meningkatkan pola kerjasama dari yang berfokus kepada keamanan dan kestabilan wilayah, selanjutnya menginisiasikan program kerjasama ekonomi sejak dekade 1980an, sempat terlantarkan dan dihidupkan kembali pada awal 1990 oleh proposal Thailand untuk mengadakan 'free trade area'. Dengan adanya inisiasi ekonomi ini cukup menarik bagi Brunei Darussalam yang bergabung ASEAN pada 1984 diikuti Vietnam tahun 1995, Laos dan Myanmar tahun 1977, dan Kamboja tahun 1999 (Kotler, Kartajaya, \& Huan, 2014).

Didirikan pada tahun 1967, tujuan pembentukan ASEAN secara spesifik tidak untuk merespon globalisasi. Dalam perkembangangannya, kerjasama kawasan ASEAN tidak lepas dari pengaruh globalisasi (Winarno, 2008). ASEAN dapat menjadi bentuk kelompok pemimpin di Asia Pasifik yang tidak berdasarkan pada kekuasaan. Bentuk kepemimpinan ASEAN di Asia Pasifik dapat dilihat pada norma bersama, institusi, dan responnya menghadapi fenomena regional serta internasional yang didasarkan pada globalisasi (Tay, Tan, \& Kiruppalini, 2017). Hal ini dapat dilihat salah satunya pada penghilangan hambatan ekonomi alias 'free trade area' di ASEAN pada dekade 1980-1990an yang menjadikan negara anggota ASEAN sadar bahwa perlu mengembangkan kerjasama-kerjasama ekonomi lainnya.

Menindaklanjuti kesadaran kerjasama untuk membuka perekonomian demi integrasi ekonomi kawasan, terbentuklah kesepakatan mengenai pembentukan ASEAN Community yang ditandai dengan adanya kesepakatan The Declaration of ASE AN Concord II, atau lebih dikenal dengan Bali Concord II dalam KTT ASEAN ke-9 tahun 2003. Pembentukan ASEAN Community berlandaskan pada tiga pilar, yaitu ASEAN Security Community ( $A S C$ ), ASEAN Economic Community (AEC), dan ASEAN Socio-cultural Community (ASCC) yang diberlakukan bagi setiap negara anggota ASEAN. Peningkatan kerjasama ekonomi kawasan Asia Tenggara terdapat dalam satu dari tiga pilar ASEAN Community, yaitu ASEAN Economic Community (AEC). The $12^{\text {th }}$ ASEAN Summit pada Januari 2007, pemimpin perwakilan tiap negara menyatakan komitmen kuat mereka terhadap adanya ASEAN Community dan menginginkan ASEAN Community dapat dipercepat pelaksanaannya pada tahun 2015. Ditandatanganinya Cebu Declaration 2015 menjadi tanda bahwa ASEAN Community telah resmi dijalankan (Pangestu, 2009).

\section{Liberalisasi Sektor Penerbangan ASEAN}

Dalam menganalisis topik permasalahan, penulis mengikuti pendekatan liberalisme institusional yang menyinggung tentang peran institusi internasional. Negara-negara anggota terlibat dalam suatu institusi memiliki kesadaran bahwa setiap kebijakan dari institusi tersebut merupakan keinginan yang telah disepakati bersama dengan negara-negara lain untuk mengatur hubungan di masa yang akan datang. Dengan kata lain, bergabungnya suatu negara dalam institusi internasional akan mengaburkan sebagian kedaulatan negaranya untuk mencapai kepentingan bersama. Oleh karena itu, keberadaan negara dan keterlibatannya dalam sebuah kesepakatan atau institusi tertentu diyakini mampu meningkatkan hubungan baik dengan negara-negara anggotanya. Dalam konteks adopsi pemikiran dan tata perilaku yang menjadi bagian dari keyakinan bersama, maka kehadiran institusi mampu menjamin stabilitas hubungan antar aktor internasional (Ikbar, 2014).

Dalam rangka membentuk kesamaan tindakan, instutusi menerapkan kebijakan tertentu sebagai hasil dari persetujuan para anggotanya dengan tujuan untuk menciptakan integrasi. Dalam tulisan ini, ASEAN sebagai institusi internasional memberlakukan kebijakan ASEAN Open Sky pada tahun 2015 guna mendorong liberalisasi sektor penerbangan internasional yang sebut sebagai 
ASEAN Single Aviation Market (ASAM) (ASEAN, n.d.). ASEAN menginisiasikan liberalisasi penerbangan, yang merupakan 1 dari 11 sektor usulan sebagai upaya integrasi MEA (Bofinger, 2008). Seperti yang diketahui bersama, masyarakat ekonomi ASEAN mengupayakan kemakmuran, daya saing tinggi, dan integritas pasar ekonomi dan produksi yang berpusat di ASEAN dan ASAM merupakan salah satu pilar untuk memfasilitasi kebebasan, efisiensi, keselamatan, dan pergerakan yang aman bagi manusia dan barang didalam hingga keluar ASEAN (ASEAN, n.d.).

Liberalisasi penerbangan akan berdampak pada 10 negara anggota ASEAN yang menyetujui. Liberalisasi akan mendorong peningkatan kualitas penerbangan setiap negara ASEAN baik dari regulasi, kualitas bandara, regulasi penunjang, hingga maskapai. Peningkatan kualitas penerbangan di willayah Asia Tenggara akan mendorong persaingan negara-negara Asia Tenggara agar mampu bersaing diluar kawasan dalam era globalisasi. Lebih baiknya lagi, maskapai mampu melakukan ekspansi keluar kawasan. Persiapan setiap negara menghadapi liberalisasi penerbangan akan berbeda-beda tergantung dari kesiapan pemerintah, sarana penerbangan, prasarana penerbangan, dan maskapai masing-masing negara. Jumlah armada maskapai dan jumlah bandara setiap negara menjadi faktor utama kesiapan setiap negara ASEAN menghadapi liberalisasi penerbangan ini.

Di Indonesia, pada tahun 2015 tercatat 16 perusahaan penerbangan yang beroperasi. Angka ini terbilang banyak, penyebabnya adalah faktor mudahnya izin mendirikan perusahaan penerbangan dari pemerintah pada tahun 1999. Dampak tak langsung dari kebijakan tersebut adalah sejak tahun 2002 terjadi peningkatan rata-rata 22\% per tahun bagi penumpang pesawat domestik (Mujiono, 2015). Pemerintah Malaysia menerapkan kebijakan berbeda dengan Indonesia dimana pemerintah Malaysia sangat mendukung pembukaan jalur internasional Kuala-LumpurSingapura. Dampaknya adalah pada kemampuan perusahaan penerbangan melakukan ekspansi secara internasional (Fauzi, 2015). Dari segi maskapai, kedua negara memiliki Garuda Indonesia dan Malaysia Airlines sebagai maskapai full service, serta Lion Air dan Air Asia sebagai maskapai Low Cost Carrier (LCC). Sementara, Singapura memiliki keunggulan dari segi maskapai dan kesiapan sarana-prasarana. Keterlibatan Singapura dalam mengelola ruang udara kepulauan Riau karena memiliki kapabilitas pelayanan navigasi penerbangan yang memadai dibanding Indonesia menjadi salah satu contoh kesiapan Singapura di sektor sarana-prasana penerbangan (Rumuat, 2018).

Penelitian ini berusaha memahami dampak penerapan kebijakan ASEAN Open Sky bagi Singapura, Indonesia, Malaysia, dan Filipina. Pemilihan keempat negara ini dikarenakan keempat negara tersebut merupakan negara dengan kualitas penerbangan dan sarana-prasarana terbaik jika dibandingkan dengan keenam negara anggota ASEAN lainnya. Urgensi dari penelitian ini adalah meninjau dampak ASEAN Open Sky bagi Singapura, Indonesia, Malaysia, dan Filipina menggunakan analisa kekuatan, kelemahan, kesempatan dan ancaram dari adanya ASEAN Open Sky bagi daya saing negara-negara ASEAN. Pemilihan keempat negara ini juga dengan alasan bahwa keempat negara tersebut berlokasi terpisah dengan Mainland Asia Tenggara yang dapat diakses menggunakan transportasi darat sehingga bagi keempat negara ini, sektor penerbangan merupakan hal yang penting. Berdasarkan uraian diatas, menarik untuk menganalisis bagaimana dampak ASEAN Open Sky bagi Singapura, Malaysia, Indonesia, dan Filipina serta negara mana yang paling diuntungkan dan dirugikan dengan adanya kebijakan tersebut.

\section{Metode Penelitian}

Penulis menggunakan metode penelitian deskriptif dengan pendekatan kualitatif. Teknik pengumpulan data melalui studi dokumen dan studi literatur berbagai informasi yang berasal dari 
jurnal, buku, surat kabar, website, baik yang bersifat daring maupun cetak. Metode penelitian kualitatif bertujuan untuk menggambarkan suatu fenomena tertentu, baik yang bersifat alamiah maupun rekayasa atau untuk menentukan ada tidaknya keterkaitan diantara suatu gejala dengan gejala lainnya yang relevan dengan penelitian. Selain itu, tulisan ini bersifat deskriptif analitik, yaitu dengan menganalisis fakta-fakta yang terjadi menggunakan teori dan konsep yang memiliki keterkaitan dengan fenomena tersebut. Hasil analisis data dipaparkan dalam bentuk uraian. (Emzir, 2011).

Teknik analisis penulis bersandar pada teknik analisa SWOT oleh Freddy dengan mengidentifikasi berbagai faktor yang dijadikan acuan perumusan strategi secara sistematis. Analisa yang digunakan didasarkan pada logika yang dapat memaksimalkan kekuatan (Strength) dan peluang (Opportunity), namun secara bersamaan dapat meminimalkan kelemahan (Weakness) dan ancaman (Threat). Proses pengambilan keputusan strategis selalu berkaitan dengan pengembangan misi, tujuan, strategi, dan kebijakan yang diterapkan. Menggunakan metode ini perencanaan strategis (Strategis Planner) harus menganalisis faktor-faktor strategis (kekuatan, kelemahan, peluang, dan ancaman) dari suatu perusahaan maupun kebijakan yang diterapkan dalam kondisi yang ada pada saat ini. Hal-hal yang disebutkan diatas disebut dengan Analisis Situasi. Model analisis yang paling popular dalam Analisis Situasi adalah dengan menggunakan metode analisi SWOT (Rangkuti, 2003).

Dalam pembuatan analisis SWOT, penelitian harus menunjukkan adanya kombinasi faktor internal dan eksternal dan kedua faktor tersebut-internal dan eksternal-harus dipertimbangkan dalam analisis SWOT. SWOT terinspirasi dari singkatan lingkungan internal yaitu Strengths dan Weaknesses serta lingkungan eksternal yaitu Opportunities dan Threats yang dihadapi oleh suatu perusahaan. Penggunaan analisis SWOT adalah dengan pembandingan antara faktor eksternal Peluang (Opportunities) dan Ancaman (Threats) dengan faktor internal Kekuatan (Strengths) dan Kelemahan (Weaknesses).

\section{Hasil dan Pembahasan}

\section{Indonesia}

Indonesia kurang menyambut pemberlakuan ASEAN Open Sky-sering disebut ASEAN Single Aviation Market (ASAM). Indonesia dan Laos tercatat sebagai negara terakhir yang ratifikasi kesepatan negara-negara anggota ASEAN terhadap ASEAN Open Sky (Hana, 2018). Dengan berbagai pertimbangan pemerintah Indonesia menghadapi ASEAN Open Sky, kehadiran Garuda Indonesia sebagai maskapai full service menjadi salah satu kekuatan yang dimiliki Indonesia dalam rangka meningkatkan daya saing. Garuda Indonesia sebagai maskapai berbintang lima yang telah mendapatkan berbagai penghargaan internasional, termasuk “World's Best Cabins Crew 2017” selama empat tahun berturut-turut. Sesungguhnya keunggulan ini menjadi potensi kekuatan Indonesia dalam menghadapi persaingan dengan berbagai layanan penerbangan di tingkat ASEAN. (Garuda Indonesia, n.d.)

Berdasarkan kualitas maskapai dan layanan penerbangan, Indonesia seharusnya telah memenuhi standar internasional. Pada Juni 2018 lalu, Uni Eropa telah menghapus Indonesia dari daftar maskapai penerbangan yang tidak aman. Seperti yang diketahui bersama, Indonesia pernah menjadi bagian dari daftar EU Air Safety List pada tahun 2007. Pemerintah EU menyatakan bahwa keamanan penerbangan Indonesia kurang memadai dan tidak aman digunakan oleh masyarakat sehingga dilarang untuk melakukan penerbangan menuju negara-negara anggota Uni Eropa (EU, 2018). Dihapusnya Indonesia dari EU Air Safety List setelah sebelas tahun berjalan 
mengindikasikan bahwa Indonesia telah berbenah di sektor penerbangan, terutama kapasitas pelayanan dan keamanan berbagai maskapai dalam memenuhi kebutuhan masyarakat dunia.

Menindaklanjuti daya saing penerbangan di tingkat internasional, Garuda Indonesia menjadi bagian dari keunggulan Indonesia di era ASEAN Open Sky. Dengan mempertimbangkan kekuatan berbagai maskapai full service dari negara-negara ASEAN seperti Malaysia Airlines, Singapore Airlines, Cebu Pacific, dan Thai Airways, prestasi Garuda Indonesia tentunya layak menjadi bagian dari promosi Indonesia untuk melayani penerbangan internasional. Data pada tabel 1 menunjukkan adanya harapan baik dari minat konsumen terhadap pelayanan maskapai Garuda Indonesia. Dalam kurun waktu 2013-2017, tiap tahunnya terjadi peningkatan penumpang dimana pada 2013 sebanyak 19.620.319 penumpang dan jumlahnya kian bertambah setiap tahunnya hingga 23.962.932 penumpang pada tahun 2017 (Garuda Indonesia, 2018).

Tabel 1. Jumlah Penumpang Garuda Indonesia tahun 2013-2017

\begin{tabular}{cccc}
\hline Tahun & Domestik & Internasional & $\begin{array}{c}\text { Jumlah Penumpang Domestik } \\
\text { dan Internasional }\end{array}$ \\
\hline 2013 & 15.849 .746 & 3.770 .573 & 19.620 .319 \\
\hline 2014 & 17.604 .623 & 3.983 .901 & 21.588 .524 \\
\hline 2015 & 19.412 .993 & 4.173 .069 & 23.586 .062 \\
\hline 2016 & 19.487 .372 & 4.433 .049 & 23.920 .421 \\
\hline 2017 & 19.172 .026 & 4.790 .904 & 23.962 .932 \\
\hline
\end{tabular}

Sumber : Garuda Indonesia (2018)

Tidak hanya dari jumlah penumpang, peningkatan juga terjadi pada jumlah kargo Garuda Indonesia. Sebanyak 403,9 juta kg kargo dibawa Garuda Indonesia pada tahun 2014. Sempat turun menjadi 351,7 juta kg di tahun 2015, sektor kargo Garuda Indonesia tahun 2016-2018 kembali meningkat dengan jumlah total 415,8 juta $\mathrm{kg}$ di tahun 2016, 446,7 juta kg di tahun 2017, dan 453,7 juta $\mathrm{kg}$ di tahun 2018 (Garuda Indonesia, 2018).

Lion Group, sebagai maskapai Low Cost Carrier terbesar di Indonesia juga berperan mendukung promosi pelayanan penerbangan Indonesia di tingkat internasional. Lion Group membuka maskapai baru di Kamboja tahun 2018 sebagai perwakilan maskapai low cost carrier asal Indonesia yang melakukan ekspansi dengan wujud pembuatan maskapai baru di salah satu negara mainland Asia Tenggara (CNBC, 2018).

Tantangan dan ancaman Indoneisa tidak lepas dari faktor geografi. Sebagai negara kepulauan yang meliputi darat dan laut mengakibatkan Indonesia harus memiliki banyak bandara. Kuantitas bandara dibutuhkan demi menunjang kemudahan transportasi domestik dan akomodasi antar wilayah. Pada 2012, terdapat 29 bandara internasional dari total 233 bandara (Association, 2012). Dengan adanya ASEAN Open Sky, kuantitas bandara yang tinggi tersebut tidak menguntungkan Indonesia. Hal ini dibuktikan dengan 29 bandara yang melayani penerbangan internasional, Air Asia mendominasi pasar tersebut dengan presentase 22\% sedangkan Garuda Indonesia hanya $14 \%(C A P A, 2018)$. Indonesia menjadi pasar yang menguntungkan bagi Air Asia karena dominasi maskapai asal Malaysia tersebut lebih dominan dibanding maskapai Indonesia.

Selain Malaysia, maskapai asal Singapura juga mendominasi pasar Indonesia. Jumlah bandara internasional yang dimiliki kedua negara memiliki perbedaan yang sangat signifikan yaitu 
1 bandara Singapura dan 29 bandara Indonesia. Untuk penerbangan Singapura-Indonesia, bandara Changi memiliki rute ke 14 kota di Indonesia dimana dari rute tersebut didominasi oleh maskapai asal Singapura. Singapore Airlines mendominasi rute Singapura-Indonesia dengan 33\%, sedangkan Garuda Indonesia dan Lion Air di peringkat ketiga dengan masing-maisng 11\%. Peringkat kedua diduduki oleh Air Asia dengan 18\% (CAPA, 2013).

\section{Malaysia}

Malaysia cenderung sangat siap menghadapi ASEAN Open Sky. Kuala Lumpur secara geografis menjadi penghubung menuju Singapura, menjadikan bandara KLIA (Kuala Lumpur International Airport) menjadi pusat transit penerbangan internasional yang strategis. Lebih jauh, Malaysia dan Singapura tidak hanya memiliki letak geografis yang strategis dan infrastruktur bandara yang unggul, tetapi juga maskapai nasional full service dan low cost carrier berdaya saing internasional (Saraswati, 2011). Selain itu, Malaysia yang hanya memiliki delapan bandara internasional didukung dengan KLIA yang merupakan bandara dengan performa terbaik-setelah Changi-di Asia Tenggara menjadi kekuatan Malaysia bersaing dalam pasar penerbangan ASEAN. ASEAN Open Sky yang diinisiasi sejak tahun 2000-an mendorong pemerintah Malaysia mempromosikan pelayanan KLIA sebagai bandara bertaraf internasional.

Kesadaran Malaysia terhadap padatnya lalu lintas penerbangan ketika ASEAN Open Sky diberlakukan, mendorong pemerintah mengembangkan KLIA menjadi dua sektor, yaitu KLIA 1 dan KLIA 2. Pembangunan KLIA 2 dipersiapkan untuk menghadapi penerbangan low cost carrier. Perbaharuan KLIA dikerjakan sejak tahun 2010 dan proyek diselesaikan tahun 2014. Pada bulan Mei 2014 bandara KLIA2 dibuka dan mulai beroperasi (KLIA2, n.d.).

Keunggulan penerbangan Malaysia didukung dengan adanya Malaysia Airlines, namun belum mengungguli Singapore Airlines dan Garuda Indonesia di sektor maskapai full service (Hananto, 2012). Hal ini dilihat dari jumlah penumpang tahunan dan jumlah armada pesawat Malaysia Airlines (17,04 juta penumpang dan 79 armada) tidak sebanyak Garuda Indonesia (17,1 juta penumpang dan 142 armada) (Salikha, 2018). Malaysia Airlines yang masih dibawah Singapore Airlines dan Garuda Indonesia juga dapat dilihat dari penghargaan Maskapai Terbaik 2019 versi Skytrax dimana Singapore Airlines di peringkat dua dunia, Garuda Indonesia di peringkat 12 dunia, sedangkan Malaysia Airlines tidak masuk di 12 besar maskapai dunia (Kompas, 2019).

Keunggulan maskapai Malaysia didominasi oleh AirAsia dari sektor low cost carrier. Dampak dari ASEAN Open Sky terhadap AirAsia adalah dari bentuk ekspansi yang dilakukan perusahaan asal Malaysia ini ke berbagai negara ASEAN (MIDF, 2014). Salah satu keberhasilannya adalah mendominasi $22 \%$ penerbangan internasional Indonesia. Keberhasilan ekspansi tersebut berdampak pada kenaikan jumlah penumpang tiap tahunnya yaitu: 22,1 juta di tahun 2014; 24,5 juta di tahun 2015; 26,4 juta di tahun 2016; 39,1 juta di tahun 2017; dan 44,4 juta di tahun 2018 (Statista, 2019).

Dengan demikian, berdasarkan letak geografis yang strategis, kualitas dan kuantitas bandara, dan jumlah maskapai yang memadai, memberikan peluang besar bagi Malaysia menghadapi ASEAN Open Sky. Pertama, Malaysia sebagai negara penghubung ke Singapua berdampak pada meningkatnya jumlah kunjungan turis asing baik ke bandara maupun negara dengan tujuan transit. Di segi maskapai, AirAsia dengan penerbangan murahnya yang sangat bersaing dengan maskapai lain menjadi daya tarik penumpang. Didukung dengan pelayanan fasilitas dan keselamatan yang tinggi, dampak dari ASEAN Open Sky ini semakin mendukung 
AirAsia sebagai maskapai berbiaya rendah terbaik dunia yang telah didapatkannya selama 10 tahun berturut-turut (Skytrax, 2018).

Kelemahan Malaysia terhadap ASEAN Open Sky, seperti yang telah dituliskan diatas, terdapat pada maskapai Malaysia Airlines yang kurang mampu bersaing dengan Garuda Indonesia dan Singapore Airlines di kancah internasional. Daya saing yang tinggi akan menjad kelemahan bagi Malaysia Airlines dan berdampak akan menjadi ancaman. Disisi lain, hadirnya ASEAN Open Sky menjadikan persaingan semakin panas dengan hadirnya low cost carrier lain seperti Scoot dan Cebu Pacific dalam hal ini akan menantang pasar AirAsia.

\section{Filipina}

Keputusan Filipina menyepakati ASEAN Open Sky tidak jauh dari keinginan Filipina untuk memajukan sektor penerbangan baik dari maskapai, infrastruktur bandara, hingga operasional kerja bandara (Saraswati, 2011). Kekuatan Filipina terletak pada sektor maskapai Cebu Pacific dan pariwisatanya, dimana Filipina menjadi salah satu tujuan pariwisata dunia dengan keberadaan pulau Palawannya. Filipina sebagai salah satu negara Asia dengan perkembangan ekonominya yang relatif lambat, memaksimalkan potensi pariwisata yang dimilikinya untuk meningkatkan perekonomian. Menjadi negara kepulauan yang memiliki lebih dari 7.500 pulau didominasi dengan pantai berpasir putih, gunung, dan air terjun seharusnya bias menjadikan Filipina pusat wisata, namun hanya total 6 juta pengunjung asing yang datang pada tahun 2016 — setengah dari pengunjung asing Vietnam, Singapura, dan Indonesia. Kurangnya pengunjung ke Filipina dianggap karena mahalnya pesawat menuju atau meninggalkan Filipina dibanding ke Indonesia atau negara-negara mainland ASEAN (Oplas, 2018).

Cebu Pacific, maskapai berbiaya rendah asal Manila, Filipina yang mulai menanjak pemasarannya sejak pertama kali berdiri. Saat ini Cebu Pacific telah beroperasi melayani penerbangan domestik dan internasional. Awal mulanya Cebu Pacific melayani penerbangan domestik hanya ke 37 tujuan di Filipina. Menindaklanjuti keterbukaan atau liberalisasi penerbangan di Asia Tenggara yang telah diberlakukan sejak 2015, Cebu Pacific saat ini mulai melakukan ekspansi jalur penerbangan internasional ke 26 kota dari 15 negara dari Asia, Australia, Timur Tengah, termasuk penerbangan ke Bali, Indonesia (Aquino, 2018).

Keberadaan Cebu Pacific yang mampu bersaing dalam persaingan pasar penerbangan murah akan mendukung Filipina dari berbagai sektor termasuk ekonomi dan pariwisata. Semakin meningkatnya rasio kedatangan wisatawan asing ke Filipina akan membantu pemasukan devisa negara, begitu juga maskapai yang padat akan memberikan devisa bagi negara. Menurut Business World dengan diberlakukannya ASEAN Open Sky, sektor ekonomi Filipina melalui sektor maskapai penerbangan akan berdampak pada peningkatan PDB negara lebih dari 100 kali lipat di tahun 2030 (Oplas, 2018). Dengan data ini, maka dapat dilihat seberapa berpengaruhnya sektor maskapai mampu memberikan masukan bagi devisa negara.

Kelemahan bagi Filipina sebagai negara kepulauan, hampir sama seperti Indonesia yang memiliki banyak bandara internasional. Dengan adanya 12 bandara internasional, maka Filipina ditakutkan akan menjadi tujuan perdagangan produsen Asia. Dengan kata lain, Filipina akan menghadapi kenyataan menjadi negara yang konsumtif. Selain itu, lokasi geografis Filipina yang jauh dengan negara ASEAN lainnya menjadikan akomodasi akan cukup mahal. Hal inilah yang menjadikan Filipina kurang menarik bagi wisatawan asing. 


\section{Singapura}

Singapura merupakan negara dengan luas wilayah yang sangat kecil dibandingkan negara anggota ASEAN lainnya. Dengan luas wilayah yang kecil, lantas tidak membuat perekonomian Singapura terhambat. Sebuah negara yang telah memisahkan diri dari Malaysia tahun 1965, hingga tahun 1990an mengalami pertumbuhan ekonomi yang tinggi sehingga disebut sebagai NIC (Newly Industrialized Country) dan sampai saat ini, Singapura disebut sebagai negara dengan standar kehidupan yang tinggi. Bukan tanpa alasan, letak geografis singapura yang berada di pusat transit transportasi air mendukung perekonomian negara kecil ini berkembang dengan pesat (Lambert, 2018).

Selain dari sektor air, udara Singapura diuntungkan dengan dijadikannya Singapura sebagai negara hub penerbangan Asia Tenggara. Negara hub adalah negara yang kerap menjadi lokasi transit penerbangan sebelum ke tujuan akhir. Misal penerbangan Indonesia-Thailand menggunakan low cost carrier, penerbangan akan melakukan transit di Singapura sebagai negara hub.

Keuntungan yang menjadi kekuatan bagi Singapura dengan adanya ASEAN Open Sky adalah Singapura memiliki Changi dengan kualitas bandara terbaik se-Asia Tenggara dan kedudukan maskapai nasional mereka yang sangat kuat, baik maskapai full service (Singapore Airlines) dan low cost carrier (Silk Air dan Scoot) (Saraswati, 2011). Alasan inilah mengapa Singapura dianggap sebagai negara paling siap menghadapi kebijakan ASEAN Open Sky. Diberlakukannya ASEAN Single Aviation Market akan berpengaruh pada tuntutan maskapai low cost carrier untuk menawarkan harga yang lebih murah dibanding sebelum diberlakukannya ASEAN Open Sky, karena persaingan pasar akan memaksa mereka untuk memberikan harga yang lebih murah.

Singapura hanya memiliki satu bandara saja, baik domestik maupun internasional, yaitu Changi International Airport. Singapura yang hanya dengan satu bandara, memiliki akses untuk melayani lebih dari 100 maskapai dengan berbagai tujuan ke sekitar 400 bandara dan 100 negara (Changi, 2018). Luasnya akses yang diberikan bandara Changi ke berbagai bandara dan berbagai negara akan memberikan keuntungan yang besar bagi Singapura, yaitu peningkatan traffic pengunjung Changi-dan Singapura tentunya.

Dibanding tahun 2014 dengan total pengunjung 54,10 juta, peningkatan pengunjung yang tiba di Changi Airport terus naik di tahun setelahnya, yaitu tahun ketika ASEAN Open Sky sudah berlakukan. Peningkatan pengunjung cukup signifikan terjadi, terutama di tahun 2017 yang mencapai 62,22 juta pengunjung. Tahun 2018 tidak dapat dijadikan acuan, karena data yang terhitung hanya hingga November 2018 sehingga data yang dibandingkan tidaklah apple to apple. Daripada itu, di tahun 2018-hingga November-pengunjung yang telah datang telah melampaui total pengunjung di tahun 2014, 2015, dan 2016. (Changi, 2018).

Dari sektor maskapai, keberhasilan Singapura diwakilkan oleh maskapai full service asal Singapura sendiri, yaitu Singapore Airlines. Sebagai bukti bahwa Singapore Airlines telah berkembang pesat selama beberapa tahun kebelakang, ekpspansi luar biasa telah dilakukan Singapore Airlines beberapa bulan lalu dimana setelah rasio penerbangan yang sangat signifikan terjadi di kawasan Asia Tenggara, Singapore Airlines menyelesaikan perjalanan pertamanya dari Singapura menuju Newark, Amerika Serikat secara langsung alias direct flight_yang menjadikannya penerbangan terlama untuk pesawat komersial—dengan lama perjalanan hampir 18 jam non-stop pada 12 Oktober 2018 (BBC, 2018).

Adanya ASEAN Open Sky menjadikan Singapura sadar betapa pentingnya untuk memiliki maskapai berbiaya rendah untuk bersaing dengan AirAsia dan Lion Air yang sudah menjadi icon 
maskapai low cost di Asia Tenggara. Dipandang Silk Air tidak mampu bersaing, Singapore berupaya untuk mentransfer sejumlah pesawat dari Silk Air kepada Scoot yang dinilai memiliki daya tarik pasar lebih tinggi dibanding Silk Air. Penambahan unit penerbangan untuk maskapai Scoot tentunya akan memberikan dampak bagi Changi dan Singapura karena seluruh penerbangan Scott akan berhenti ke Changi Airport dan Singapura sebagai negara hub untuk selanjutnya melanjutkan ke rute tujuan (Jaramaya, 2018).

Kesiapan Singapura menghadapi ASEAN Open Sky dengan kombinasi maskapai dan bandara, menjadikannya kekuatan yang sangat terlibat jelas bagi Singapura. Terbukti, memiliki maskapai terbaik didukung bandara internasional terbaik dunia menjadikan Singapura yang sangat sering dikunjungi wisatawan internasional. Tahun 2014, sebelum diberlakukannya ASEAN Open Sky, wisatawan asal Asia Tenggara yang masuk ke Singapura sebanyak 6,113,076 jiwa (Board, 2015). Terjadi peningkatan wisatawan asing asal Asia Tenggara pada tahun 2017-dua tahum setelah ASEAN Open Sky diberlakukan-dengan total 6,225,114 jiwa (Board, 2018). Upaya Singapore Airlines yang begitu massive beberapa tahun belakang-dengan menciptakan Scoot sebagai pesaing di low-cost carrier-berhasil memberikan dampak positif bagi peningkatan wisatawan asing asal Asia Tenggara.

Tabel 2. Ringkasan Pembahasan terkait Pro dan Kontra ASEAN Open Sky bagi Indonesia, Malaysia, Filipina, dan Singapura

\begin{tabular}{|c|c|c|c|c|}
\hline State & Indonesia & Malaysia & Filipina & Singapura \\
\hline $\begin{array}{c}\text { Letak } \\
\text { Geografi }\end{array}$ & $\begin{array}{c}\text { Letak geografi yang } \\
\text { luas menghadirkan } \\
\text { banyak bandara } \\
\text { internasional } \\
\text { sehingga menjadi } \\
\text { pasar potensial } \\
\text { maskapai asing. } \\
\text { Indonesia menjadi } \\
\text { lebih konsumtif } \\
\text { dibanding Singapura } \\
\text { dan Malaysia } \\
\text { dengan bandara } \\
\text { internasional yang } \\
\text { lebih sedikit }\end{array}$ & $\begin{array}{c}\text { Berada di antara } \\
\text { negara ASEAN } \\
\text { sehingga menjadi } \\
\text { negara hub sangat } \\
\text { menguntungkan } \\
\text { bagi Malaysia }\end{array}$ & $\begin{array}{c}\text { Kehadiran } 12 \\
\text { bandara } \\
\text { internasional } \\
\text { Filipina } \\
\text { menjadikan negara } \\
\text { ini satu pasar } \\
\text { potensial ekspansi, } \\
\text { sehingga Filipina } \\
\text { menjadi negara } \\
\text { konsumtif seperti } \\
\text { Indonesia }\end{array}$ & $\begin{array}{c}\text { Letak geografi } \\
\text { mendukung Singapura } \\
\text { menjadi negara hub } \\
\text { penerbangan dan dengan } \\
\text { adanya ASEAN Open } \\
\text { Sky, semakin } \\
\text { memperbesar peluang } \\
\text { Singapura menjadi negara } \\
\text { singgah. } \\
\text { Berbeda dengan } \\
\text { Indonesia dan Filipina, } \\
\text { Singapura hanya memiliki } \\
\text { satu bandara } \\
\text { internasional } \\
\end{array}$ \\
\hline $\begin{array}{c}\text { Daya } \\
\text { Saing } \\
\text { Maskapai }\end{array}$ & $\begin{array}{c}\text { Memberikan } \\
\text { keterbukaan akses } \\
\text { bagi Garuda } \\
\text { Indonesia dan Lion } \\
\text { Air sehingga } \\
\text { mampu melakukan } \\
\text { ekspansi }\end{array}$ & $\begin{array}{c}\text { Ekspansi Air Asia } \\
\text { sebagai maskapai } \\
\text { low cost menjadikan } \\
\text { ASEAN Open Sky } \\
\text { instrumen yang } \\
\text { tepat untuk } \\
\text { mendatangkan } \\
\text { wisatawan, baik } \\
\text { sebagai tujuan } \\
\text { utama atau transit }\end{array}$ & $\begin{array}{l}\text { Dengan adanya } \\
\text { ASEAN Open Sky, } \\
\text { maskapai Cebu } \\
\text { Pasific mulai } \\
\text { bersaing dengan } \\
\text { maskapai low cost } \\
\text { lainnya }\end{array}$ & $\begin{array}{l}\text { Adanya ASEAN Open } \\
\text { Sky, penerbangan kargo } \\
\text { Singapura yang } \\
\text { sebelumnya nomor } \\
\text { wahid di kawasan kalah } \\
\text { bersaing dengan } \\
\text { penerbangan kargo } \\
\text { Indonesia yang mulai } \\
\text { mengambil kedudukan } \\
\text { Singapura }\end{array}$ \\
\hline
\end{tabular}

Bagi Singapura, diberlakukannya ASEAN Open Sky juga menjadikan kelemahan di salah satu sektor, yaitu penerbangan angkutan barang/kargo. Fokus penerbangan Singapura yang lebih berfokus pada pengembangan bandara dan maskapai komersial, menjadikan Singapura kurang berfokus pada sektor penerbangan kargo. Sebelumnya, pasar penerbangan kargo di kawasan Asia Tenggara dikuasai oleh tiga negara, yaitu Singapura, Vietnam, dan Thailand. Ketika pasar kargo masih dikuasai ketiga negara tersebut, negara yang menjadi pasar dan produsen barang-seperti 
Indonesia—cukup dirugikan karena barang yang akan dikirim atau diterima diwajibkan untuk masuk terlebih dahulu ke bandara Singapura, Vietnam, atau Thailand sebagai penguasa pasar. Kebijakan ini cukup merugikan dalam hal efektivitas dan efisiensi baik waktu maupun biaya (Yovanda, 2018).

Sektor pasar penerbangan kargo ini akan menjadi ancaman bagi Singapura jika Singapura kurang memperhatikan kualitas dan efektivitas jalur penerbangan kargo yang dimilikinya. Ancaman ini jika dibiarkan, akan menjadi peluang bagi negara lain dengan traffic penerbangan kargo lebih tinggi bagi Singapura. Terbukti dengan langkah Indonesia yang akan mengambil pasar kargo yang sebelumnya dimiliki Singapura, Thailand, dan Vietnam.

Setiap negara memiliki pro dan kontra terhadap pelaksanaan kebijakan ASEAN Open Sky. Letak geografi dan daya saing maskapai menjadi pusat dari pembahasan dimana masing masing sektor tersebut memberikan sudut pandang kesiapan masing-masing negara terhadap pelaksanaan ASEAN Open Sky. Kebijakan Open Sky ini pada akhirnya menciptakan persaingan yang lebih intense bagi sektor penerbangan kawasan Asia Tenggara. Masing-masing negara dituntut untuk dapat bergerak cepat dalam daya saing maskapai serta memanfaatkan letak geografi yang dimiliki sehingga dapat bersaing dengan negara lain di kawasan Asia Tenggara.

\section{Kesimpulan}

Kebijakan ASEAN Open Sky yang diinisiasikan oleh ASEAN memberikan banyak dampak bagi negara-negara anggota ASEAN, baik positif maupun negatif. Setiap negara perlu melakukan perbaikan dan pengembangan dari berbagai sektor termasuk infrastruktur dan fasilitas bandara untuk dapat bersaing dalam ASEAN Open Sky. Maskapai juga nampaknya perlu diberikan perhatian khusus untuk menjadi kompetitor maskapai lain. Tentunya respon setiap negara sangat penting berpengaruh untuk menunjukkan seberapa jauh kesiapan negara, terutama bagi Indonesia, Singapura, Malaysia, dan Filipina yang tidak merupakan bagian dari mainland ASEAN sehingga kesiap sektor penerbangan sangat penting untuk mempermudah akses dan akomodasi.

Berdasarkan pembahasan diatas, dapat dilihat kesiapan Malaysia dan Singapura menghadapi ASEAN Open Sky. Dengan berbagai faktor di pembahasan, dengan adanya ASEAN Open Sky Singapura dan Malaysia menjadi negara yang diuntungkan dengan fasilitas dan jumlah bandara, maskapai, dan lokasi geografi yang strategis. Berbeda dengan Indonesia dan Filipina dengan jumlah bandara cukup banyak namun tidak didukung dengan fasilitas yang baik dibanding Changi dan KLIA, dan fakta bahwa Indonesia dan Filipina dapat menjadi pasar potensial sehingga akan menjadi negara yang konsumtif, maka Indonesia dan Filipina menjadi negara yang dirugikan dengan dampak adanya ASEAN Open Sky.

\section{Daftar Pustaka}

Aquino, M. (2018, April 23). Southeast Asia's Top Budget Airlines. Retrieved from tripsavvy: https://www.tripsavvy.com/southeast-asias-top-low-cost-airlines-1629922

Association, F. (2012). Market Analysis Airport Sector 2012. Zoetermeer: FME-CWM.

BBC. (2018, Oktober 13). Mengintip penerbangan terjauh tanpa henti dengan Singapore Airlines. Retrieved from BBC Indonesia: https://www.bbc.com/indonesia/majalah-45840070

Board, S. T. (2015, April 7). 2014 International Visitor Arrivals Statistics. Retrieved from stb.gov.sg: https://www.stb.gov.sg/statistics-and-marketinsights/marketstatistics/ivastat_dec_2014\%20(updated\%2007apr15).pdf 
Board, S. T. (2018, Juni 19). 2017 International Visitor Arrivals Statistics. Retrieved from stb.gov.sg: https://www.stb.gov.sg/statistics-and-marketinsights/marketstatistics/visitor\%20arrivals \%202017.pdf

Bofinger, H. C. (2008). Status of the Liberalization of Air Transport among the ASEAN Countries. ICAO AND THE WORLD BANK DEVELOPMENT FORUM.

CAPA. (2018, Juni 8). Indonesia: International Aviation, Rapid Growth and Strong Competition. Retrieved from CAPA: Centre for Aviation: https://centreforaviation.com/analysis/reports/indonesia-international-aviation-rapidgrowth-and-strong-competition-410927

CAPA. (2013, Maret 1). Singapore Changi to Benefit from Continued Rapid Growth of Indonesia Market. Retrieved from CAPA-Centre for Aviation: https://centreforaviation.com/analysis/reports/singapore-changi-to-benefit-fromcontinued-rapid-growth-of-indonesia-market-99228

Changi. (21, Desember 2018). Traffic Statistics. Retrieved from changiairport.com: http://www.changiairport.com/corporate/about-us/traffic-statistics.html

Cipto, B. (2010). Hubungan Internasional di Asia Tenggara. Yogyakarta: Pustaka Pelajar.

CNBC. (2018, Juni 22). Sengit di ASEAN, Lion Air Buka Maskapai di Kamboja Tahun Ini. Retrieved from CNBC Indonesia: https://www.cnbcindonesia.com/news/20180622155000-4-20112/sengit-di-aseanlion-air-buka-maskapai-di-kamboja-tahun-ini

Emzir. (2011). Metodologi Penelitian Kualitatif Analisis Data. Jakarta: Rajawali Pers.

EU. (2018, Juni 14). Aviation Safety: Commission removes all airlines from Indonesia from EU Air Safety List. Retrieved from Mobility and Transport: https://ec.europa.eu/transport/modes/air/news/2018-06-14-commission-updates-euair-safety-list_en?fbclid=IwAR36Hh_tRK18whnM9esLkNgaRHZf3ZDmMGuvZPrILVeGjtAN_1-ra2kd2w

Fauzi, A. (2015). Competitive Advantage Industri Penerbangan Malaysia terhadap Pelaksanaan ASEAN Single Aviation Market. Jurnal Analisis Hubungan Internasional Vol. 4 No. 1, 1357.

Garuda Indonesia. (2018). Data Historikal Operasional. Retrieved from Garuda Indonesia: https://www.garuda-indonesia.com/id/id/investor-relations/company-data/historicaloperating-data/index.page

Garuda Indonesia. (n.d) Garuda Indonesia Awarded "World's Best Cabin Crew" for the Fourth Consecutive Year. Retrieved from Garuda Indonesia: https://www.garudaindonesia.com/other-countries/en/news-and-events/garuda-dinobatkan-sebagaiworld-best-cabin-crew.page\#

Hana, O. D. (2018, September 09). Indonesia Seharusnya Jadi Leading Role di Asean Open Sky. Retrieved from Ekonomi \& Bisnis: https://ekonomi.bisnis.com/read/20180909/98/836726/indonesia-seharusnya-jadileading-role-di-asean-open-sky

Hananto, A. (2012, Juni 13). Head to Head: Garuda Indonesia and Malaysia Airlines. Retrieved from Good News From Indonesia: https://www.goodnewsfromindonesia.id/2012/06/13/head-to-head-garuda-indonesiaand-malaysia-airlines

Ikbar, Y. (2014). Metodologi dan Teori Hubungan Internasional. Bandung: Refika Aditama. 
Jackson, R., \& Sorensen, G. (2010). Introduction to International Relations: Theories and Approaches. United Kingdom: Oxford University Press.

Jaramaya, R. (2018, Juni 22). Singapore Airlines Ekspansi ke Bisnis Penerbangan Murah. Retrieved from Republika Ekonomi: https://www.republika.co.id/berita/ekonomi/bisnisglobal/18/06/22/papc7r383-singapore-airlines-ekspansi-ke-bisnis-penerbangan-murah

KLIA2. About KLIA2. Retrieved from klia2.info: http://www.klia2.info/about-klia2

Kompas. (2019, Juni 24). Maskapai Terbaik 2019 Versi Skytrax, Singapore Airlines Turun Tahta.

Retrieved from

Kompas.com:

https://biz.kompas.com/read/2019/06/24/162443328/maskapai-terbaik-2019-versi-

skytrax-singapore-airlines-turun-tahta

Kotler, P., Kartajaya, H., \& Huan, H. d. (2014). Think New ASEAN! Rethinking Marketing Towards ASEAN Economic Comunity. Singapura: McGraw-Hill Education.

Lambert, T. (2018). A Brief History of Singapore. Retrieved from localhistories.org: http://www.localhistories.org/singapore.html

MIDF. (2014). Malaysia Equity Towards ASEAN Open Sky. Kuala Lumpur: MIDF Research.

Mujiono, D. I. (2015). Tantangan Industri Penerbangan Indonesia Menuju ASEAN Open Sky Policy. Jurnal Interdependence Vol. 3 No. 1, 56-69.

Oplas, B. S. (2018, Desember 10). The ASEAN Single Aviation Market. Retrieved from BusinessWorld: https://www.bworldonline.com/the-asean-single-aviation-market/

Pangestu, M. E. (2009). Competitiveness Towards ASEAN Economic Comunity. Journal of Indonesian Economiy and Business Vol. 24 No. 1, 22-32.

Rangkuti, F. (2003). Analisis SWOT Teknik Membedah Kasus Bisnis: Reorientasi Konsep Perencanaan Strategis untuk Menghadapi Abad-21. Jakarta: Gramedia Pustaka Utama.

Rumuat, W. R. (2018). Persamaan Perspektif sebagai Penyebab Penguasaan FIR Singapura di Ruang Udara Kepulauan Riau. Journal of International Relations Vol. 4 No. 3, 313-323.

Salikha, A. (2018, Januari 7). Head to Head: Garuda Indonesia VS Malaysia Airlines. Retrieved from SEASIA: https://seasia.co/2018/01/07/head-to-head-garuda-indonesia-vsmalaysia-airlines

Saraswati, B. (2011). An On-going Process: Overview of the ASEAN Open Sky Agreement. Jakarta: ERIA Internship.

Statista. (2019, Juni). Number of passengers carried by AirAsia from fiscal year 2014 to 2018. Retrieved from Statista: https://www.statista.com/statistics/1030569/airasia-numberof-passengers/

Tay, S. S., Tan, C., \& Kiruppalini, S. (2017). Global Megatrends: Implications for the ASEAN Economic Community. Jakarta: ASEAN Secretariat.

Winarno, B. (2008). Politik Regionalisme dan Tantangan ASEAN Di Tengah Arus Besar Globalisasi. Jurnal Ilmu Politik Hubungan Internasional Vol. 5 No. 2, 1.

Yovanda, Y. R. (2018, Januari 8). ASEAN Open Sky Resmi Berlaku, RI Ambil Pasar Kargo Singapura. Retrieved from Sindonews.com: https://ekbis.sindonews.com/read/1075502/34/asean-open-sky-resmi-berlaku-riambil-pasar-kargo-singapura-1452259710 